Digitalizacja archiwalnych numerów czasopisma naukowego Analecta Cracoviensia 1-24 (1969-1992) i ich publikacja w otwartym dostępie - zadanie finansowane w ramach umowy 672/P-DUN/2017 ze środków Ministra Nauki i Szkolnictwa Wyższego przeznaczonych na działalność upowszechniającą naukę

\title{
TEOLOGICZNE ROZUMIENIE PRAWA NATURALNEGO NA TLE ENCYKLIKI „HUMANAE VITAE”
}

\section{WPROWADZENIE}

W gorącej dyskusji, jaka rozwinęła się natychmiast po ogłoszeniu encykliki Humanae vitae, punktem szczególnie mocno atakowanym była przyjęta przez autora encykliki koncepcja prawa naturalnego. Nie możemy sobie na tym miejscu pozwolić na szczegółowe omówienie wszystkich wypowiedzi podnoszących trudności przeciw pojęciu prawa naturalnego. Zasygnalizuję tylko kilka typowych wypowiedzi, które pozwolą uchwycić sam problem postawiony w tytule.

B. Häring zarzucał Pawłowi VI, jakoby odszedł od teologii Vaticanum II i cofnął się na pozycje biologizmu w etyce małżeńskiej ${ }^{1}$. A. Hertz podobnie zarzuca papieżowi hołdowanie koncepcji starożytnej, nacechowanej fizycyzmem. $\mathrm{Z}$ niezrozumiałych powodów tenże autor przeciwstawia prawo naturalne zarówno ewangelii jak metafizyce ${ }^{2}$. Poja-

1 Häring B., Liebe ist mehr als Gebot, München u. Freiburg im Br. 1968, 121. Podobne trudności posiadają i inni autorzy. Np. L. M. Weber (w: Matrimonio, Sessualità, Verginità, Morcelliana 1968, 37) uważa, że nie można odwoływać się do „natury” jako do centralnej normy etycznej życia małżeńskiego. Wiele wskazuje na to, że Häring w swej koncepcji personalizmu ulega sugestiom spirytualistycznym i egzystencjalistycznym. Przykładem jednym $z$ wielu jest książka Personalismus in Philosophie und Theologie, München u. Freiburg im Br. 1968, 23, gdzie całą osobę ludzką sprowadza do „relacji dialogicznej”, zwłaszcza w kontekście „przeżywanej miłości”. Zastrzega się wprawdzie przeciw jednostronnemu pojmowaniu „osoby”, ale nie daje żadnego rozwiązania, 'które gwarantowałoby uniknięcie nieporozumień. Również Grygiel S., w art. Ludzka twarz prawa natury, „Znak" 21 [1968, n. 175 (1)] 1-30, nie daje w pełni zadowalającego wyjaśnienia stosunku "osoby” do „natury”, mimo wielu cennych i głębokich analiz.

2 Por. „Der Prediger und Katechet”, 107 (1968) 607. Również „Tygodnik Powszechny", 22 (1968), n. 35) 1 n. 
wiały się również twierdzenia stawiające prawo naturalne całkowicie poza zakresem prawa Bożego ${ }^{3}$.

Mimo dość różnych nieraz sformułowań, zasadniczy ton i kierunek zarzutów jest dość jednoznaczny. Na ogół wszystkie wypowiedzi polemiczne sprowadzały dyskusję na płaszczyznę czysto naukową, ignorując teologiczny ( $w$ najgłębszym znaczeniu) charakter dokumentu nauczania papieskiego. Prawdopodobnym celem wyboru takiej metody dyskusji było uchylenie się od przyjęcia wypowiedzi Pawła VI jako autorytatywnej i podtrzymywanie $\mathrm{w}$ dalszym ciągu stanu wątpliwości teologicznej w etycznej problematyce regulacji poczęć. Takie ustawienie dyskusji kryło w sobie jednak ogromne niebezpieczeństwo dla niej samej. Odrzucenie teologicznych kryteriów w analizie pojęcia prawa naturalnego, a co za tym idzie, odrzucenie kościelnej wykładni prawa naturalnego (jako w rzeczywistości obowiązującego prawa Bożego) uzależnia zrozumienie sensu prawa naturalnego od dominujących współcześnie kierunków filozoficznych, które zagubiły lub odrzuciły metafizyczne pojęcie natury. Z kolei więc cały sens pojęcia „natury” oraz „prawa natury" zależy od obiegowych wyobrażeń i nawyków intelektualnych urabianych pod wpływem prądów umysłowych i teorii rozwijających się $\mathrm{w}$ cieniu nauk przyrodniczych i tworzących zręby światopoglądu technicznego.

Nietrudno było zauważyć, że natchnieniem dla autorów odrzucających Pawłową koncepcję prawa naturalnego był egzystencjalistyczny personalizm. Z treści zarzutów miało zawsze wynikać, że uznawanie tzw. „prawidłowości bytowych” i jakichkolwiek obiektywnych czynników decydujących o normie etycznej, zagraża możliwości rozwoju osobowego a nawet wyklucza jakoby samą możliwość samookreślenia, która jest istotnym składnikiem wolności ludzkiej. Ograniczenie człowieka do tego tylko, co jest „naturalne”, (głoszą przeciwnicy encykliki) jest istotnym zacieśnieniem ludzkiej egzystencji, ponieważ oznacza wykluczenie twórczej inicjatywy oraz rozumnej interwencji człowieka w dziedzinę natury, a w konsekwencji oznacza negację całej współczesnej kultury, która powstała właśnie w wyniku opanowania ,ślepych sił przyrody". I w tym właśnie momencie zaczyna się tragizm. Człowiek uwalnia się od „prawa natury” głoszonego przez Kościól, po to, by - jak sobie obiecuje - uwolnić się od „biologicznych norm w etyce”, a w gruncie rzeczy po to, by wpaść w tryby cywilizacji technicznej, gdzie wszystkie sprawy ludzkiego ciała są traktowane na równi ze ślepymi siłami przy-

3 Chodzi tu o prof. N. Abbagnano, który zarzuca encyklice prymitywne pojecie prawa naturalnego, a nawet odrzuca tożsamość prawa naturalnego $\mathrm{z}$ prawem Bożym. Profesor atakuje również tradycyjne pojęcie celu w małżeństwie. $\mathrm{Z}$ poglądami Abbagnano polemizuje na lamach „Osservatore Romano" autor podpisujący się f.a., 108 (1968, $\mathrm{nr}$ 181) 1, z dnia 8 sierpnia. 
rody, a więc podlegają jedynie kryteriom przyrodniczym i technicznym. Pragnąc uwolnić się od determinizmu biologicznego, przeciwstawia osobę naturze, sprowadzając tę ostatnią do poziomu przyrody.

Pełniejsze ukazanie problemu wymaga zwrócenie uwagi na fakt, że już Sobór toczył się w czasie mocno nieprzychylnym dla koncepcji prawa naturalnego, co dało znać o sobie tak w samym przebiegu dyskusji soborowych, jak i ujawniło się w pierwszych komentarzach zwłaszcza do Gaudium et Spes. M. L. Heylen, swoiście interpretując fakt złagodzenia w Gaudium et Spes terminologii naturalno-prawnej (w rozdziale o małżeństwie), posuwa się do śmiałego twierdzenia, że choć mianowicie „prawa natury” trzeba szanować, to jednak jakikolwiek respekt należny naturze nie może przeszkodzić człowiekowi, by wnikał w jej wnętrze i by nią kierował do zamierzonych przez siebie celów: Wiedza - według cytowanego autora - wprowadza w naturę element „kultury”, co odnosi się również do funkcji życiowych człowieka. Interwencja $w$ te funkcje nie jest nieładem, lecz oznacza podniesienie natury na poziom ludzki. Tzw. ,wyższy porządek”, to nie porządek kosmosu, ale porządek człowieka. Zbliżona do Boga osoba ludzka stanowi najwyższe i jedyne kryterium całego porządku uważanego za ludzki i etyczny w ścisłym znaczeniu ${ }^{4}$.

W tym kontekście nie jest dziwne, że egzystencjalizm i naturalizm w pojmowaniu ,osoby” i „,natury” pojawia się również we wnioskach osławionej Komisji Papieskiej zajmującej się zagadnieniem populacji, rodziny i regulacji poczęć. W tej części raportu, w której wyraziła swoją opinię ,,postępowa" większość, znajdujemy coś w rodzaju posądzenia o zabobon, tych wszystkich, którzy w prawach natury doszukują się bezpośredniego wyrazu woli Bożej ${ }^{5}$. Zwolennicy refom w etyce małżeńskiej uważali, że człowiek jako istota osobowa i wolna może rozporządzać danymi naturalnymi. Dlatego po ogłoszeniu encykliki $\mathrm{Hu}$ manae vitae wszyscy zwolennicy antykoncepcji uważali, że powinni protestować przeciw ograniczeniu wolności człowieka.

W wyniku pojawienia się skrajnych tendencji filozoficznych i teologicznych wytworzyła się sytuacja, w której jakakolwiek wypowiedź Urzędu Nauczycielskiego narażona była natychmiast na sprzeczne reakcje wśród teologów. Takie zachowanie się teologów może być wprawdzie łatwo wytłumaczalne prawami ludzkiej psychologii, natomiast nie może znaleźć uzasadnienia $\mathrm{w}$ prawach myślenia teologicznego. Niepokojącym i trudnym do wytłumaczenia faktem było przeoczanie i pomijanie w dy-

4 Heylen M. L., La dignité du mariage et de la famille, w: L'Église dans le monde de ce temps, Paris 1967, $163 \mathrm{nn}$.

5 Por. Documentum syntheticum de moralitate regulationis nativitatum, I, 1; II, 1: wyd. Paupert J. M., Contrôle des naissances et théologie. Le dosier de Rome, Paris 1968, 156-158. 
skusjach religijnego i kościelnego (a więc nadprzyrodzonego) autotrytetu Magisterium. Dotyczy to w szczególny sposób dyskusji nad koncepcją prawa naturalnego. Niektórzy teologowie uważali, że Kościół nie ma nic do powiedzenia $\mathrm{w}$ tym przedmiocie. Cała bowiem dziedzina „,natury" leży jakoby poza zakresem zbawczej misji Kościoła. Jeżeli nawet Kościół w ciągu wieków posługiwał się argumentem prawa naturalnego to czynił to rzekomo zupełnie $\mathrm{z}$ innych motywów, np. $\mathrm{z}$ chęci „odzyskania utraconego świata", ponieważ przy pomocy prawa naturalnego może oddziaływać również na tych ludzi, którzy nie uznają Objawienia. W dziedzinie małżeńskiej argument prawa naturalnego nie przedstawia tych walorów, dzięki którym mógłby służyć za podstawę uzasadnienia normy etycznej. Prawo naturalne jako czerpane z rzeczywistości eksperymentalnej nie ma wartości absolutnej i ponieważ nie korzysta $z$ tej powagi, co doktryna wiary, może przestać oddziaływać na sumienie ludzkie $\mathrm{z}$ chwilą pojawienia się przeciw niemu jakichkolwiek wątpliwości. L. Weber, który zbiera właśnie wszystkie te trudności, uważa, że Kościół nie dysponuje stałą i jednoznaczną koncepcją prawa naturalnego. Pewne bowiem koncepcje przyjęte przez Kościół zmieniały się niezależnie od niego, albo też Kościół sam czerpał odnośne pojęcia z różnych źródeł, stosownie do potrzeby ${ }^{6}$.

$\mathrm{Tu}$ zdaje się, dotykamy sedna zagadnienia. Chodzi o to, czy nauka Kościoła wyrażona $\mathrm{w}$ jakimkolwiek dokumencie może być interpretowana $\mathrm{W}$ oderwaniu od istotnego charakteru tego dokumentu. Jeżeli tak, to zdani jesteśmy na subiektywizm a w najlepszym razie - na racjonalizm. Cała dyskusja dotyczyłaby wtedy definicji (filozoficznej) pojęć, ich proweniencji, sensu i zakresu twierdzeń w świetle logiki i nauk pokrewnych. Jeżeli jednak nie, to pierwszym zadaniem teologa stojącego w obliczu dokumentu nauczania kościelnego jest zrozumieć w świetle wiary, co Kościół w tym dokumencie głosi i przyjąć głoszoną prawdę w sposób odpowiedni do jej treści jak i do sposobu jej ogłoszenia. Tego rodzaju stosunek nie wyklucza możliwości studium historyczno-krytycznego nad samym dokumentem. Ale tego rodzaju studium odbywa się przy założeniu, że sama treść doktryny kościelnej nie zależy od prywatnej opinii teologów ani od samych kryteriów filozoficznych. Odnośnie naszego zagadnienia należy zaznaczyć, że doktryna etyczna Kościoła musi być brana w swej całości i zwartości wewnętrznej oraz w łącz-

6 Weber, Matrimonio..., 18: „Cosi il diritto naturale è quasi uno strumento, con cui la gerarchia puô operare come guida oltre l'ambito della fede vera epropria e dare una configurazione normativa alla vita morale degli uomini". Arntz A., uważa prawo naturalne za "historyczne" i zmienne w swej istocie, a nawet za immanentne historii. Prawo naturalne i jego dzieje, "Concilium". Międzynarodowy Przegląd Teologiczny, 1-10 (1965-6) 363-374. Takie jednak prawo moralne miałoby więcej wspólnego z Heglem niż z Chrystusem i nie mogłoby mieć znaczenia dla historii Zbawienia. 
ności z całą substancją dogmatu. Nie wolno również pomijać faktu, że Kościół, budując teologiczną koncepcję prawa naturalnego, korzysta w sposób kompetentny z osiągnięć myśli ludzkiej i z dorobku każdej filozofii. Z chwilą jednak, kiedy włącza takie nowe elementy w swoją syntezę, nadaje im często nowe znaczenie. Znaczenie takich przyswojonych pojęć i twierdzeń nie jest już tyle zależne od źródła, z którego je czerpano, ile od tej nowej całości, w którą zostały włączone. Teologiczny sens prawa naturalnego, nie opiera się zatem na jakiejś historycznie znanej i może przebrzmiałej teorii, nie jest tym bardziej jakimś uogólnionym wnioskiem nauk empirycznych, ani średnią wypadkową moralnej czy psychologicznej świadomości ludzi aktualnie żyjących. Teologiczne i chrześcijańskie pojęcie prawa naturalnego wymaga $w^{\prime}$ sposób nieodzowny $\mathrm{z}$ jednej strony poprawnej filozofii bytu, a $\mathrm{z}$ drugiej strony czerpie światło $\mathrm{z}$ dogmatu stworzenia, Wcielenia i Odkupienia. Chrystologia jest podstawą antropologii chrześcijańskiej nawet $\mathrm{w}$ tym, co dotyczy natury człowieka. Wydaje się, że dopiero w świetle tych principiów można i należy rozumieć sens prawa naturalnego w encyklice Humanae vitae.

\section{POJĘCIE NATURY W ENCYKLICE}

\section{STWORZONY CHARAKTER NATURY}

Pojęcie prawa jest analogiczne do bytu, dlatego również na płaszczyźnie teologicznej zrozumienie pojęcia prawa naturalnego wymaga wniknięcia w istotę tej rzeczywistości, dla której jest ono normatywną definicją. Zatem konieczne jest zrozumienie, $\mathrm{z}$ jakim pojęjęciem natury Paweł VI wiąże pojęcie prawa. Otóż w tym punkcie doktryna papieża nie odbiega od stałej nauki Kościoła Powszechnego, który zawsze wiąże pojęcie natury (za Biblią) z dogmatem stworzenia. Stwierdzenia tego nie podważa fakt, że tradycja teologiczna posługuje się pojęciami filozoficznymi czerpanymi jeszcze od tych myślicieli, którzy o dogmacie stworzenia nie wiedzieli. Zrozumienie natury jako stworzonej jest czymś nieodzownym dla zrozumienia prawa naturalnego, tak, jak mówi o nim encyklika Humanae vitae. Dlatego słusznie można było oczekiwać odwołania się do tego dogmatu we wspomnianym dokumencie. I tak w n. 13 kilkakrotnie powtarza się termin "Bóg-Stwórca" ? Również wymowny jest n. $31^{8}$. Skoro Bóg jest Stwórcą wszystkiego, to znaczy, że natura stworzona w całości jest dziełem Boga, czyli w całej

7 „Bóg, Stwórca wszechrzeczy...”, HV, n. 13: Encyklika Humanae vitae, AAS, 60 (1968) 481-503.

8 "...zachowując prawa wszczeplione w jego naturę przez najwyższego Boga", Hiv, n. 31. 
swej bytowości i w całym swoim sensie normatywnym oraz w całej swej potencjalności. Innymi słowami byt stworzony jest dziełem Boga nie tylko w tym, że jest czym jest (aktualnie), ale i w tym, co się składa na jego dalsze stawanie się, jego samourzeczywistnienie, również przy udziale wolności, gdy chodzi o byty rozumne.

W świecie przenikniętym Stwórczą Wszechmocą, wolność ludzka przedstawia się jako sfera osobliwa i tajemnicza, tak dalece, iż niektórzy uważają, że wolność daje możność wymknięcia się spod absolutnej dominacji Boga. Tymczasem i sama wolność jest po prostu dziełem Bożym: Bóg ją stwarza i potwierdza: i jeżeli gdzie — to właśnie wewnątrz niej jest najbardziej obecny. Bóg stwarza wolność, aby człowiek, stworzony na obraz Boży, był na sposób ludzki (tj. mocą świadomego chcenia) przyczyną swej ludzkiej doskonałości. Człowiek jednak dopiero wtedy doskonali siebie prawdziwie, kiedy najpierw afirmuje swoje człowieczeństwo jako dzieło Boże i jako dar Boży. Człowiek bowiem otrzymuje dla siebie całą treść ludzkiego bytu w taki sposób, w jaki ów byt już był chciany i miłowany przez Boga. W ten sposób wola Boga i wola człowieka spotykają się w tym samym przedmiocie (może lepiej: podmiocie) tak blisko, jak to jest tylko możliwe. Nie jest sprzeczne mówić $\mathrm{w}$ tym kontekście o dialogu czy spotkaniu z Bogiem, pod warunkiem, że uznaje się, iż sama płaszczyzna, na której w ogóle dialog z Bogiem jest możliwy (chodzi nie tylko o wolność ludzką, ale i o skierowane doń wezwanie łaski), jest darem Boga. Tworzenie własnej doskonałości jest niewątpliwie tworzeniem siebie samego (w pewien sposób), ale człowiek nie może tego naprawdę uczynić inaczej, niż chciał i zapoczątkował sam Bóg.

Wyrażona co dopiero ogólna zasada objawia swoją wyjątkową doniosłość właśnie $\mathrm{w}$ dziedzinie, którą objaśnia encyklika Humanae vitae. Z woli Bożej bowiem ciało człowieka jest płciowe, a płciowość mężczyzny i kobiety ma charakter ludzki i osobowy. Pozbawienie ludzkiego ciała i jego czynności charakteru płciowego w wyniku jakiegoś wewnętrznego przeorganizowania i przestawienia na płaszczyznę mechaniki czy technologii, byłoby więc nie tyle uczłowieczeniem natury, ile odczłowieczeniem osoby i małżeństwa na skutek depersonalizacji natury. Nie byłoby to $\mathrm{w}$ żaden sposób samopotwierdzeniem się wolności, lecz właśnie oddanie samej wolności w zależność od elementów poza-ludzkich czy nawet poniżej-ludzkich i poniżej-osobowych. Byłoby to narzuceniem człowiekowi nowej ontologicznej konstytucji $\mathrm{i}$ to $\mathrm{w}$ sposób degradujący naturę ludzką do poziomu zwykłego mechanizmu. Wolność stałaby jedynie na usługach tego mechanizmu i jej rola sprowadzałaby się wyłącznie do świadomych aktów autoabdykacji.

Powołując się na dogmat stworzenia Paweł VI pozostawał w całko- 
witej zgodzie z doktryną Vaticanum II, gdzie stworzoność świata została mocno podkreślona ${ }^{9}$. Stworzoność bytu skończonego i stworzony charakter wolności stanowią podstawowe stwierdzenia, od których zależy pełne zrozumienie natury człowieka.

\section{NATURA CZEOWIEKA}

W kontekście dopiero co przypomnianych twierdzeń, szczególnego podkreślenia domaga się osobowy charakter natury ludzkiej. Ten głównie charakter sprawia, że człowiek zajmuje odrębne i wyjątkowe stanowisko $\mathrm{W}$ stosunku do reszty świata widzialnego. W doktrynie Vaticanum II osobowy charakter natury ludzkiej został nie tylko dostrzeżony, ale bardzo mocno zaakcentowany, tak, że można mówić o personalistycznym charakterze antropologii głoszonej przez Sobór ${ }^{10}$. Drugą doniosłą właściwością tej antropologii jest dążenie do integralnego ujęcia powołania człowieka, nie tylko w zakresie indywidualnym ale i wspólnotowym.

Pojęcie powołania, którym posłużył się Sobór, nie jest jakąś dedukcją filozoficzną, lecz opiera się na fakcie historyczno-zbawczym, polegającym na tym, że Bóg stał się człowiekiem, przez co każdy człowiek został pociągnięty do udziału w życiu Bożym ${ }^{11}$. Właśnie z tego punktu widzenia Wcielenie można uważać za dostateczne wypełnienie Stworzenia. Stąd aktualnie istniejąca natura ludzka (aktualnie istniejąca ludzkość) może być $\mathrm{w}$ pełni zrozumiana jedynie $\mathrm{z}$ uwzględnieniem odniesienia do Chrystusa ${ }^{12}$.

W dyskusji nad Humanae vitae odwoływano się niekiedy do głoszonej przez Sobór personalistycznej koncepcji człowieka, aby ją przeciwstawić tej antropologii, jaką zakłada i wykłada encyklika Pawła VI.

9 ,... autonomia ... odpowiada ... także woli Stwórcy. Wszystkie rzeczy bowiem, z samego faktu, że są stworzone, mają własną trwałość, prawdziwość, dobroć i równocześnie własne prawa i porządek, które człowiek winien uszanować... Kto pokornie i wytrwale usiłuje zbadać tajniki rzeczy, prowadzony jest niejako, choć nieświadomie, ręką Boga, który wszystko utrzymując, sprawia, że rzeczy są tym, czym są ... Lecz jeśli słowom, ,autonomia rzeczy doczesnych" nadaje się takie znaczenie, że rzeczy stworzone nie zależą od Boga, a człowiek może ich używać bez odnoszenia ich do Boga, to każdy, uznający Boga, wyczuwa, jak fałszywe są tego rodzaju zapatrywania. Stworzenie bowiem bez Stworzyciela zanika", Gaudium et Spes, n. 36, w: Sobór Watykański II. Konstytucje - Dekrety - Deklaracje, Poznań 1968, 811-987.

10 Gaudium et Spes, n. 3 ; n. 12; n. 14. Por. Alszeghy Z., La dignità della persona umana, w: La Costituzione pastorale sulla Chiesa nel mondo contemporaneo, Torino 1966, $427 \mathrm{nn}$.

${ }_{11}$ „Bóg bowiem powołał i powołuje człowieka, aby przylgnął do Niego całą swoją naturą", Gaudium et Spes, n. 18.

12 „Tajemnica człowieka wyjaśnia się naprawdę dopiero w tajemnicy Słowa Wcielonego..."; „Skoro w Nim przybrana natura rie ulega zniszczeniu, tym samym została ona wyniesiona również w nas do wysokiej godności...", Gaudiuin et Spes, nn. 10; 22. 
Pretekstem dla takiego przeciwstawienia był fakt, że Paweł VI dość często akcentuje naturalne i obiektywne podstawy norm etycznych. Jakiekolwiek przeciwstawienie natury i osoby, przypominające orientalno-dualistyczną lub monistyczno-dialektyczną koncepcję bytu, jest w zakresie nauki katolickiej — po prostu nieporozumieniem. Treści pojęć „osoby" i natury nie pozwalają wprawdzie na postawienie formalnego znaku równości, ale też i nie dają się od siebie realnie oddzielić. Rozumna natura bezosobowa jest po prostu nie do pomyślenia, a osoba bez natury nigdzie nie istnieje. Pomiędzy „osobą" i ,naturą" istnieje relacja transcendentalna. Obie realności nawzajem się przenikają i dopełniają. Wszystko, co jest naturą, uczestniczy w godności osobowej, a raczej - jest osobowe. Natura rozumna nie wypowiada się inaczej, jak w sposób osobowy: sama natura nosi w sobie podstawę i moc takiego działania. Osoba działa właśnie mocą tejże natury i na podstawie tej konstytucji normatywnej, jaką Bóg zapisał w jej bycie.

Sama realizacja owego Bożego planu, odbywająca się zgodnie $z$ naturą rozumnej wolności, nie jest mechanicznym odtworzeniem programu ,zakodowanego" w bycie - jak to próbują imputować przeciwnicy prawa naturalnego, lecz opiera się na jego zrozumieniu i świadomym przyjęciu, zgodnie $z$ racjonalno-dynamiczną strukturą osoby. Takie pojęcie człowieka pozwala a zarazem nakazuje traktować również biologiczną stronę natury ludzkiej jako prawdziwie ludzką, bo należącą do osoby. To określenie: „należy do osoby” trzeba rozumieć nie w sens:e rzeczowego przywłaszczenia, lecz $\mathrm{w}$ sensie istotowego ukonstytuowania w podmiocie. Co więcej, jeśli pojęcie „własności” odnoszące się do biologii ludzkiej, miałoby mieć w tym kontekście zarówno bardziej uwznioślone jak i bardziej adekwatne znaczenie, należałoby powiedzieć, że skoro osoba ludzka - mocą swej transcendencji - podlega tylko Bogu, to i ciało ludzkie w ścisłym znaczeniu jest własnością Boga. Jeśli bowiem osoba ludzka jest wyjęta od wszelkich form rzeczowego rozporządzania, to odnosi się do całej osoby człowieka. Zgodnie z tym - wszystko, cokolwiek istnieje w człowieku na sposób osobowy, może być dosięgane przez człowieka jedynie w Bogu i poprzez Boga. W tym świetle jest zrozumiałe, dlaczego wszelkie dysponowanie biologią płci jest ludzkie jedynie w kontekście sakramentu — w tajemnicy Jedności Boga i człowieka - i dlatego próba traktowania biologii ludzkiej jako ,tylko" biologii, która otrzymywałaby po raz pierwszy swój ludzki sens dopiero w wyniku użycia jej przez człowieka dla zamierzonych przez się celów, jest teologicznym, antropologicznym i etycznym absurdem ${ }^{13}$. (Ze

13 Olejnik S., Katolicka etyka seksualna, Warszawa 1966, 91: ,...dojrzenie konieczności biologicznych, zagwarantowanie im miejsca w życiu ludzkim, uznanie ich podstawowego sensu, nie może uwłaczać godności człowieka. Podstawowym 
względu na zacieśnienie tematu zasadniczo do etycznego prawa naturalnego, nie zajmujemy się tu zagadnieniem tzw. natury „niższej”, choć zagadnienie to posiada wysoką rangę $\mathrm{w}$ teologii Vaticanum II 14, a także w Humanae vitae zajmuje niepoślednie miejsce ${ }^{15}$.)

\section{POJECIE PRAWA NATURALNEGO W ENCYKLICE „HUMANAE VITAE”}

\section{NATURALNE PRAWO MORALNE - WYRAZEM WOLI BOGA}

Etyczne prawo naturalne, na które powołuje się Paweł VI w Humanae vitae, nie jest jakąś kontrowersyjną koncepcją filozoficzną czy przyrodniczą, lecz wyrazem woli Boga-Stwórcy. Jest to ta właściwość prawa naturalnego, na której papieżowi szczególnie zależy. Właśnie odwołanie się do stworzenia pomaga papieżowi obronić się przed zarzutem hołdowania takiej czy innej koncepcji filozoficznej. Skoro bowiem byt

celem, elementarnym sensem życia seksualnego jest utrzymywanie istnienia rodzaju ludzkiego. Uznanie tego w teologii działania człowieka nie jest degradacją tego działania, lecz przeciwnie, czymś nawskroś właściwym i rozumnym".

14 Bardzo aktualny jest tu rozdział III Konstytucji Gaudium et Spes, tj. „O aktywności ludzkiej w świecie” zwłaszcza nn. 33-36.

15 ,... człowiek dokonał ... zdumiewającego postępu $\mathrm{w}$ opanowaniu i racjonalnym wykorzystaniu sił przyrody... (naturae viribus ... componendis), HV, n. 2. W n. 7 słowo „,naturalia” oznacza to, co doczesne. W n. 8 jest mowa o ,ślepych siłach przyrody". Także „zwykły impuls popędu lub uczuć" (... de mero vel natuare vel affectuum impetu, in. 9) oznacza ,naturę" o ile ona odróżnia się ad człowieka, lub raczej od pełnego człowieka. Jeszcze n. 16 mówi o ,irrationalis natura” - o nierozumnej naturze. Natura tu jest ,ślepa” i „nierozumna” tylko w tym znaczeniu, że działa na mocy praw koniecznych, to jest niezależnych w swym zdeterminowaniu of nakazu rozumnej woli stworzeń. Chodzi tu więc albo o byty nieobdarzone rozumem, albo same siły popędowe, które $w$ swym stadium spontanicznym nawet u człowieka wyprzedzają śwadomą decyzję woli. Jednak już i ta „natura ślepa” posiada właściwe sobie, wewnetrzne i racjonalne uporządkowanie, zarówno strukturalne jak dynamiczno-funkcjonalne. To podstawowe ukierunkowanie i "usensownienie" natury jest wewnętrznym składnikiem stworzonego ładu, ponieważ jest bezpośredrim skutkiem Pierwszej Przyczyny. Zadanie człowieka polega nie na przeinaczaniu obiektywnego ładu (sensu) natury, lecz na jego zrozumieniu, co jest pierwszym warunkiem, aby człowiek odnalazł swoje ludzkie miejsce w świecie stworzonym, a zarazem w pewien sposób wciąż współstwarzanym (mianowicie przy proporcjonalnym współudziale człowieka, jako stworzonego Obrazu Bożego). Również postęp i racjonalne wykorzystanie sił przyrody domagają się koniecznie zrozumienia jej praw oraz działania zgodnego $\mathrm{z}$ wykrytą prawidłowością (np. loty kosmiczne). Jednak prawidłowość przyrodnicza nie jest sama z siebie normą etyczną; otrzymuje wartość ludzką i etyczną przez to, że staje się ontologiczną podstawą praw osoby ludzkiej lub staje się wewnątrz-przedmiotowym składnikiem podmiotowego działania osobowego. Rozumne działanie, w oparciu o odczytany sens stworzenia ,zespala z wolą Stwórcy"- (HV, n. 16). Rozumne działanie kieruje wolę ku duchowym wartościom, nie czyniąc jej nigdy służką automatyzmu popędów, a tym bardziej ofiarą nieładu namiętności. W tym świetle antykoncepcja jest degradacją zarówno natury jak i osoby rozumnej i wolnej, ponieważ jest sprowadzeniem funkcji płciowych do poziomu bezosobowego mechanizmu, bowiem rolę kierowniczą, jaka z natury przypada rozumowi i duchowej woli, przejmuje technologia. 
skończony, jako stworzony, (jak to już powiedzieliśmy wyżej), jest w całości dziełem Boga, to znaczy, że jest dziełem Boga również w swym ładzie normatywnym, który $\mathrm{z}$ woli Stwórcy tkwi w stworzonym bycie. Stąd wynika, że ów ład normatywny jest rzeczywiście wyrazem woli Boga. A jeśli tak, to nie jest on czystą konkluzją filozoficzną, lecz realnością stworzoną. „Prawo bowiem naturalne jest wyrazem woli Boga (mówi encyklika) i jego wierne przestrzeganie jest ludziom konieczne do zbawienia" 16.

Ład normatywny, określający działanie człowieka, objawia się również poprzez biologię człowieka (jak zresztą objawia się poprzez inne uwarunkowania bytu ludzkiego). Paweł VI dlatego nie chce pozostawić najmniejszej wątpliwości co do tego, że również prawa biologiczne, kierujące rzeczywistością płci, są prawami ustalonymi przez Boga ${ }^{17}$. $\mathrm{Pa}-$ pież jednak rozmyślnie używa terminu leges naturales na oznaczenie praw życia ludzkiego wyrażonych $\mathrm{w}$ biologii płci, aby odróżnić prawo biologiczne od prawa etycznego w ścisłym sensie. Jeśli jednak twierdzi się, że prawo biologiczne nie jest prawem etycznym (formalnie i samo $\mathrm{w}$ sobie) to $\mathrm{z}$ tego zupełnie nie wynika, by rozumny ład, objawiony przez prawa biologiczne i poznany przez człowieka jako dobro istnienia ludzkiego, miał się znaleźć poza treściowym nawiasem norm etycznych. Widzieliśmy wyżej, że biologia ludzka nie jest obojętna dla antropologii pod pozorem, że to jest „,tylko" biologia. Podobnie ma się rzecz $z$ prawem: prawo biologiczne nie jest etycznie obojętne przez to samo, że jest to „tylko" biologiczne prawo. Prawa biologiczne określają sposób rozumnego działania człowieka właśnie dlatego, że określają - niezależnie od woli człowieka - sposób jego istnienia. Tu bowiem następuje przecinanie się linii biologii i ontologii. Etyczny sens praw biologicznych nie wynika $\mathrm{z}$ istoty biologii, lecz $\mathrm{z}$ istoty człowieka, a raczej z istoty małżeństwa, które dopiero wyjaśnia i urzeczywistnia sens płci, a więc - biologii płci.

Osoba ludzka, wzięta jednostkowo, nie ma sama $\mathrm{z}$ siebie żadnych praw w stosunku do płci. Prawo to wypływa $z$ tytułu więzi małżeńskiej, która ma charakter istotnie wyższy, niż więź biologiczna. Jednakże ta więź scala $w$ sobie także element biologii płci w taki sposób, że nadaje mu charakter absolutnie wyższy ponad to, co można by nazwać ,,prywatnym prawem do ciała”. Dlatego właśnie moralnie niemożliwa jest wszelka interwencja człowieka w sferę płci na sposób „rzeczowo-biologiczny". Sens płci wyjaśnia się i dopełnia w tej jedności, która jest równocześnie dziełem Boga i współdziałaniem człowieka. Ży-

16 Podobne stwierdzenie znajdujemy $\mathrm{w}$ nn. 10, 12, 13, 16, 19, 23, 24, 25, 26, 31 .

17 „Bóg bowiem tak mądrze ustalił naturalne prawa płodności...”, HV, 11 (Caly bowiem obiektywny porządek normatywny pochodzi od Boga. Por. HV, n. 10). 
cie płciowe (= małżeństwo) jest w rzeczywistości współstwarzaniem nowej ludzkości. Dopiero w tym wewnętrznym zwróceniu się ku Życiu Ludzkości, jakie. Bog ustawicznie stwarza, więź dwojga znajduje swoje właściwe miejsce, na którym biologia płci wchodzi $\mathrm{w}$ ontologię człowieka i małżeństwa ${ }^{18}$.

Jeśli powiedzieliśmy, że prawa płci mają sens normatywny, wciąż nie oznacza to, jakobyśmy chcieli utożsamić prawo biologiczne i prawo etyczne. Chcemy tylko powiedzieć, że zachodzi pomiędzy nimi ścisła relacja. Niewątpliwie w sferze płci działa cały zespół determinizmów i w tym zakresie, $w$ jakim działanie płci jest zdeterminowane, jest przez to samo wyjęte spod bezpośredniej determinacji woli ludzkiej. W tym też zakresie działanie płci jest „,biologiczne” w takim znaczeniu, w jakim nie może wprost przybrać wartości etycznej. Człowiek tu nie ma żadnego wpływu na to, by działanie takie było lub nie było biologiczne, dlatego zadaniem etycznym człowieka nie może być chcieć, aby tego rodzaju działanie było biologicznie poprawne. Taka postawa etyczna byłaby rzeczywiście czystym biologizmem etycznym. Takiego biologizmu encyklika jednak nigdzie nie głosi. Kiedy Paweł VI mówi o zachowaniu praw biologicznych odnoszących się do rzeczywistości płci, ma na myśli zupełnie coś innego. Mianowicie chodzi o to, że w sferze płci istnieją takie działania (a przynajmniej możliwość takich działań), w których rzeczywiście od woli człowieka zależy, czy de facto (tylko de facto, a nigdy de iure) zostanie zachowany biologiczny, czyli płciowy charakter relacji małżeńskiej. Otóż ten aspekt działania płciowego, jako podległy determinacji woli ludzkiej, może być etycznie chciany i etycznie zrealizowany. Tego rodzaju działanie biologiczne (bo płciowe!) jest wtedy działaniem ściśle ludzkim i podlega odpowiedniej normie etycznej. W tym właśnie kierunku idzie wymaganie etyczne Humanae vitae, odnoszące się do zachowania integralności biologicznej aktu płciowego. Wymaganie to jest całkowicie uzasadnione również $\mathrm{w}$ świetle prawdy, że istotę małżeństwa stanowi nie tyle sama więź osobowa, tj. wzięta w oderwaniu od funkcji rodzicielskiej, ile właśnie ścisłe i wewnętrzne zespolenie obu elementów: tj. więzi i prokreacji. Oznacza to, że w małżeństwie więź osobowa posiada charakter istotnie i wewnętrznie rodzicielski, a rodzicielstwo nie jest jedynie okolicznością ubocznie-biolo-

18 Bardziej ontyczno-jurydyczne rozwiązanie podaje Pius XII. Por.: Favara F., De iure naturali in doctrina Pii Papae XII, Desclée 1966. Na stronie 97 autor referuje pogląd Piusa XII: ,...leges physicae et biologicae ex se tales manent; sed relate ad homines, sive ipsius inforiorem partem respiciant sive eius actiones positas circa res, acquirunt valorem ethicum et fiunt etiam ipsae, vel melius res ipsis legibus signatae, fundamentum, ex quo pro hominibus exsurgunt normae juris naturalis" (por. All. Le premier Congrès, 13.IX.1952, AAS, 44 (1952) 784). Koncepcja personalistyczna, bardziej zaakcentowana w Gaudium et Spes (por. n. 76) nie wyklucza jednak, lecz dopełnia rozwiązanie Piusa XII. 
giczną, lecz posłannictwem ściśle osobowym, jako że leżącym w samym centrum osobowego powołania małżonków. Dopiero nierozerwalna jedność obu składników w małżeństwie, istniejąca nie tylko w subiektywnej intencji, ale schodząca aż do dna materialnej egzystencji człowieka, posiada charakter ściśle proporcjonalny do natury ludzkiej, ujawniając to, co jest dla tej natury istotne: substancjalne zjednoczenie elementu materialnego i duchowego.

Spojrzenie na prawo maturalne jako wyraz woli Bożej, pozwala zrozumieć jeszcze jeden aspekt norm etycznych, poznawanych za pośrednictwem natury ludzkiej. Otóż tradycja chrześcijańska pozwala patrzeć na prawo naturalne jako na składnik naturalnego objawienia. Objawienie nadprzyrodzone nie tylko nie wykluczyło, lecz jeszcze uwydatniło tego rodzaju możliwość; to zaś pozwala na wyciągnienie bardzo poważnych wniosków. Mianowicie - wolno a nawet trzeba - traktować prawo naturalne jako wy raz w ścisłym sensie - a zatem - jako słowo $\mathrm{z} \mathrm{n} \mathrm{a} \mathrm{k,} \mathrm{poprzez} \mathrm{który} \mathrm{Bóg} \mathrm{inauguruje} \mathrm{dialog} \mathrm{ze} \mathrm{stworzeniem} \mathrm{rozumnym.}$ $\mathrm{Z}$ natury zaś dialogu wynika wymaganie, że odpowiedź musi w istotny sposób nawiązywać do charakteru tego słowa, jakie zostało skierowane do człowieka. Otóż - tworzywem i zarazem formą znaku Bożego skierowanego do człowieka jest sama natura stworzona, jako dana w całości od Boga. Zatem ta sama natura musi być znakiem użytym dla odpowiedzi ze strony człowieka. Dialog o tyle będzie miał sens, o ile oprze się na prawdzie ludzkiej natury, która powinna być odczytana właściwie przez człowieka i następnie odtworzona przezeń $\mathrm{w}$ religijnym oddaniu się Bogu. Prawdy tej człowiek nie może odrzucić, bo ona stanowi jego samego: jest ,transcendentale" jego bytu. Prawda ta jest identyczna $\quad \mathrm{z}$ s e n s e m człowieczeństwa. Można ten sens wyrazić krótko w jednym zdaniu: człowiek jest a d D e u m. Człowiek nie może nigdy sądzić, że jego egzystencja jest pusta, że należy ją dopiero wypełnić jakąś wymyśloną przez siebie treścią ${ }^{19}$.

$19, \ldots .$. è significativo che tutto il valore dell'attività umana è considerato nel contesto del desegno del Creatore, come conseguenza di un investitura di Dio, per cui il genere umano prolunga l'opera del Creatore. Ciò non significa però che Dio cessa di agire nell'universo, dopo aver creato l'uomo, o anche solo, che sua azione si restringe a determinati settori. La missione ricevuta dal genere umano resta nella prospettiva della dipendenza assoluta della storia umana da Dio, unico Creatore dell'universo", Flick M., La Costituzione pastorale..., Torino 1966, 596. Natura jest stworzona, a zatem lad naturalny jest wyrazem prawa odwiecznego. „Par conséquent les exigences de cette loi, ses indications mêmes, ne peuvent pas être considerées comme purement profanes, ou n'intéressant en rien la vie morale: au contraire, elles doivent impliquer une référence à Dieu et son plan sur l'humanilé, Aubert J. M., Loi de Dieu, lois des hommes, Tournai 1964, 71. 


\section{POZNANIE PRAWA NATURALNEGO}

Prawo o którym mówimy, nazywa się „naturalnym” również ze względu na sposób, w jaki bywa (może być) poznawane. Odnośne twierdzenia znajdujemy w encyklice jasno wyrażone. Paweł VI mówi o poznawaniu prawa Bożego (naturalnego) poprzez naturę człowieka ${ }^{20}$, a także poprzez naturę małżeństwa i jego aktów ${ }^{21}$, przypominając zarazem, zgodnie $\mathrm{z}$ Vaticanum II ${ }^{22}$, że sumienie jest tylko tłumaczem prawa, czyli nie stwarza go, lecz poznaje jako obiektywnie obowiązujące ${ }^{23}$. Niektórzy autorowie (Häring) dopatrują się w sformułowaniu ipsa matrimonii eiusque actuum natura exprimit odejście od tezy soborowej, która wyraża się $\mathrm{w}$ zdaniu ex personae eiusdemque actuum natura desumptis ${ }^{24}$. Różnica jest jednak tylko w słowach, ponieważ zarówno wspólnota osób ${ }^{25}$ nie może być pojmowana jako oderwana od „instytucji” ${ }^{26}$, jak też sama instytucja nie może być pojmowana jako pozaosobowa, lecz powinna ujawniać swoją naturę $\mathrm{w}$ działaniu odznaczającym się pełną wartością osobową. Dlatego właśnie Paweł VI uważa miłość za istotny składnik instytucji małżenstwa ${ }^{27}$. Widzieliśmy już

20 HV, n. 31 .

21 ,Ad consilium Dei Creatoris accomodare, quod ... ipsa matrimonii eiusque actuum natura exprimit", $\mathrm{H}_{i}$, n. 10.

22 ,W głębi sumienia człowiek odkrywa prawo, którego sam sobie nie nakłada... Człowiek bowiem ma w swym sercu wypisane przez Boga prawo, wobec którego posłuszeństwo stanowi o jego godności..., Gaudium et Spes, n. 16.

23 „... obiektywnego porządku moralnego, ustanowionego przez Boga, którego to porządku prawdziwym tłumaczem jest prawe sumienie", HV, n. 10.

24 HV, n. 10; Gaudium et Spes, n. 51. Por. „Der Prediger und Katechet”, 107 (1968) 610. Również Häring, Liebe ist mehr als Gebot, 135; Brennpunkt Ehe oraz Krise um ,Humanae vitae”, Bergen-Enkheim 1968. Häring usiłuje interpretować Gaudium et Spes w sensie personalistyczno-spirytualistycznym, w duchu antynomii ,natury” i ,osoby", co grozi zarówno depersonalizacją natury, jak pozbawieniem osoby pełnej treści ludzkiej, a zatem dehumanizacją osoby. Osoba ludzka to jedność duchowo-materialna (Gaudium et Spes, n. 14). Prawa przekazywania życia są prawami boskimi Gaudium et Spes, n. 51. Tamże, n. 51 przypomina, że zadanie przekazywania życia nie ogranicza się do perspektyw doczesności i ma odniesienie do wiecznego przeznaczenia ludzkości.

25, ,..〈mężczyzną i niewiastą stworzył ich〉 (Rdz 1, 27); a zespolenie ich stanowi pierwszą formę wspólnoty osób. Człowiek bowiem z głębi swej natury jest istotą społeczną...", Gaudium et Spes, n. 12.

26 Gaudium et Spes, n. 24 mówi o wspólnotowym powołaniu ludzi, a n. 48 podkreśla, że małżeństwo jako wspólnota życia i miłości jest ustanowione przez Stwórę i unormowane Jego prawami; a następnie, że małżeństwo jest $z$ woli Bożej ,instytucją irwałą” i ,z samej natury swojej instytucja małżeńska oraz miłość małżeńska nastawione są na rodzenie i wychowywanie potomstwa, co stanowi jej jakby szczytowe uwieńczenie”. Por. również, n. 47.

27 „Bóg-Stwórca ustanowił je mądrze i opatrznościowo w tym celu, aby urzeczywistnić w ludziach swój plan miłości. Dlatego małzonkowie poprzez włajemne oddanie się sobie, im tylko właściwe i wyłączne, dążą do takiej wspólnoty osób, aby doskonaląc się $w$ niej wzajemnie, współpracować równocześnie z Bogiem w wydawaniu na świat i wychowywaniu nowych ludzi", HV, n. 8 (por. HV, n. 13). 
zresztą, że w świetle nauki Soboru pomiędzy aspektami „,natury” i „osoby" nie zachodzi żadna sprzeczność ${ }^{28}$.

\section{PRAWO NATURALNE NORMA CZEOWIECZEÑSTWA (NORMA HUMANITATIS)}

Krótko mówiąc, prawo naturalne, rozważane od strony treściowo normatywnej, jest prawem l u dzkim. W tym kierunku idą wszystkie wypowiedzi encykliki. W świetle Humanae vitae wszystkie prawa życia posiadają sens ludzki ${ }^{29}$. Dobro moralne jest ipso facto dobrem człowieka, natomiast zło moralne $\mathrm{z}$ samej natury rzeczy stoi $\mathrm{w}$ sprzeczności $\mathrm{z}$ dobrem człowieka ${ }^{30}$. Zachowanie praw Bożych wypisanych w naturze człowieka jest warunkiem szczęścia ${ }^{31}$. Prawo naturalne określa nie tylko sposób wzajemnego odnoszenia się w małżeństwie, ale i sposób bycia małżeństwem, bycia wspólnotą, co jest czymś istotnie więcej, niż tylko „być razem” ${ }^{32}$. Jeśli cała encyklika broni ludzkiego charakteru małżeństwa, to szczególny walor w tym względzie posiada określenie stosunku, jaki istnieje między płodnością a sensem zjednoczeniowym w więzi płciowej.

\section{ZNACZENIE PPRAWA NATURALNEGO W PORZĄDKU ŁASKI}

Jest charakterystyczne, że w dyskusji nad Humanae vitae wyszła na jaw sceptyczna jeśli nie agnostyczna postawa niektórych teologów wobec możliwości poznania prawa naturalnego, oraz jego zbawczego waloru w porządku laski. Jest to fakt o tyle ciekawy, że jeszcze nie tak dawna przecież encyklika Piusa XII Humani generis przypomniała znaną w Kościele prawdę o możliwości poznania prawa naturalnego. Odnośna teza Humani generis była tylko rozszerzającą interpretacją orzeczenia Soboru Watykańskiego I ${ }^{33}$.

Kościół ustawicznie głosił, że prawo naturalne jest prawem etycznym obowiązującym również w porządku Odkupienia i to obowiązującym nadal jako naturalne. Prawo to obecnie nic nie utraciło na swej mocy w takim samym stopniu, w jakim człowiek ochrzczony musi się

28 Por. Flick, La Costituzione pastorale..., 777 nn." Infatti l'agire umano è morale se è conforme alla natura umana considerata secondo tutti i suoi aspetti e secondo tutte le sue relazioni...”; termin ,natura”... „,non va inteso in senso statico e materiale ma in dinamico e personale, poiché nell'uomo la natura è intimamente legata alla persona, ciò chenon può dire della natura materiale", tamże, 793.

29 „modo homine digno", Gaudium et Spes, n. 51. Por. HV, nn. 21, 25, 30. W tym świetle należy rozumieć wymagania etyczne wyrażone w nn. 10-13, HV.

$30 \mathrm{HV}$, n. 18.

31 HV, n. 31 .

32 HV, nn. 8, 9, 10, 19.

33 Humani Generis, AAS, 42 (1952) 561-578. Por. Aubert, Loi de Dieu..., 93-94. 
nadal uważać za człowieka. Paweł VI wymienia równolegle „prawo naturalne” obok „ewangelicznego" ${ }^{34}$, odrzucając tym samym te tendencje, które nawiązywały do protestantyzmu.

Prawo naturalne jednak nie tylko współistnieje $z$ prawem ewangelicznym ale - analogicznie do samej natury ludzkiej, doznaje podnie-sienia i udoskonalenia. W świetle Objawienia prawo naturalne zyskuje na jasności i mocy, zostaje pełniej zrozumiane i obdarzone nowym sensem. Mówi o tym encyklika Humanae vitae ${ }^{35}$. Zresztą i w tym punkcie Paweł VI jest kontynuatorem i komentatorem Konstytucji Pastoralnej ${ }^{36}$. Nowa sytuacja człowieka, a zatem i prawa naturalnego została zwięźle i głęboko określona przez Gaudium et Spes: „Bóg objawiając siebie, objawia również człowieka — jemu samemu". Podobnie współczesna teologia mocno akcentuje prawdę, że bez objawienia nadprzyrodzonego natura ludzka i prawo naturalne nie byłyby tak jasno i wyczerpująco poznane. Co więcej, natura, będąca przedmiotem naszego poznania nie jest ani tzw. czystą naturą ani naturą doskonałą i de facto nigdy nie mieliśmy do czynienia $z$ naturą istniejącą w stanie całkowitej neutralności w stosunku do łaski. Ponieważ więc w całej swojej historii natura ludzka była w taki czy inny sposób dotknięta łaską to nie może nie mieć wpływu na rozwój jak i interpretację jej wewnętrznych tendencji. Dopiero w świetle tajemnic Chrystusowych widać wyraźnie kim jest człowiek w oczach Bożych również jako stworzenie ziemskie. Chcąc wyrazić tę prawdę niektórzy teologowie odwracając znane adagium, mówią „,natura supponit gratiam” ${ }^{37}$.

$\mathrm{Z}$ powyższego narzuca się wniosek, jasno w encyklice wyrażony, stwierdzający, że Kościół jest kompetentny głosić i autorytatywnie inter-

34 HV, n. 18. Hamel E., Loi naturelle et loi du Christ, Montreal 1964, 18, 20. „Une fois que l'homme est uni à Dieu par le lien de la charité, la loi naturelle deviendra pour lui l'expression même de cette charité que Dieu a mise dans son coeur", tamże, 21. - Dla człowieka żyjącego w łasce uświęcającej prawo naturalne, będące wezwaniem Boga Stwórcy (wypisanym w sercu), staje się wezwaniem Boga-Trójcy, pouczajacym, jak żyć w stanie usynowienia; w rzeczywiwstoścí staje się dlań prawem życia wiecznego (Mt. 19, 17). „La morale naturelle constitue donc une partie essentielle de la loi nouvelle", tamże, 23. HV, n. 4.

35 ,... prawie naturalnym, naświetlonym i ubogaconym przez Objawienie Boże",

36 Gaudium et Spes, nn. 10, 11, 13, 14, 17, zwłaszcza n. 22: „Tajemnica człowieka wyjaśnia si€̨ naprawdę dopiero w tajemnicy Słowa Wcielonego". Równiez̀ nn. $23,24,34,35-38,41,87,89$.

37 ,Une des pensées maîtresses de la Constitution pastorale ... c'est que Dieu, en se révélant à l'homme comme amour, révèle aussi à l'homme sa propre condition, le révéle à lui même... Cette pensée est primordiale parmi les fondements théologiques de la Constitution. Tout énoncé théologique, c'est-à-dre tout ce qui est affirmé de Dieu est, en même temps, un énoncé sur l'homme", Schillebeeckx E., Foi chrétienne et attente terrestre, w: L'Église dans le monde de ce temps, Paris 1967, 122. Drugie tego rodzaju fundamentalne twierdzenie brzmi: ,...le même Dieu est à la fois Créateur et Sauveur; le même Dieu est Seigneur de l'histoire humaine et de l'histoire du salut", tamże, 123. W jaki sposób Objawienie rozjaśnia, koryguje i dopełnia ludzkie poznanie zob. Alszeghy, La dignità..., 421. Zob. również Mou- 
pretować prawo naturalne ${ }^{38}$. I znowu nie jest to prywatna doktryna $\mathrm{Pa-}$ wła VI, gdyż ma on za sobą naukę Soboru, który zwłaszcza w Gaudium et Spes przypomniał, że prawo naturalne jest składnikiem porządku zbawienia. Przedmiotem uwagi Soboru jest cały człowiek ${ }^{39}$, zaś jedynie Chrystus może dopomóc człowiekowi w spełnieniu jego powołania ${ }^{40}$. Dopiero „Kościół otwiera człowiekowi oczy na sens własnej jego egzystencji czyli na najgłębszą prawdę o człowieku" i nakazuje iść za Chrystusem, co jest jedynym sposobem aby stawać się czlowiekiem ${ }^{41}$, uczy o naturalnych podstawach władzy publicznej ${ }^{42}$, explicite wymieniając przy tym prawo naturalne obok prawa ewangelicznego, broni nienaruszalnych praw osoby ludzkiej wobec roszczeń władzy politycznej ${ }^{43}$. Powołuje się też Sobór na mające już wiekową tradycję pojęcie iuris naturalis gentium ${ }^{44}$, a wreszcie, jakby dla podsumowania całości stwierdza wyraźnie, że „Kościół uczy poznawać prawo Boże i naturalne” ${ }^{45}$, stosowanie do integralnego powołania człowieka.

W konsekwencji - trzeba powtórzyć za Aubertem: „Kiedy Kościół powołuje się na prawo naturalne lub je wyjaśnia, nie czyni tego w oparciu o poznanie tylko rozumowe, jak np. filozof czy prawnik, w formie prywatnego nauczania, gdyż wtedy Kościół umniejszałby swój autorytet;

roux J., La dignité de la personne humaine, w: L'Église dans le monde de ce temps (Unam Sanctam 65, b), t. II, Paris 1967, 229 nn.

Ze stanowiska chrześcijańskiej antropologii można powiedzieć, że „Seul le Christ donne au droit naturel tout son sens. En effet, dans le domaine de la nature, le Christ, déjà en tant que Verbe de Dieu, le Logos, est intimement lié à la Création; et en tant qu'Homme-Dieu, du fait qu'il a assumé la nature humaine dans sa personne divine, il a assumé les exigences du droit naturel. Et c'est là une verité que l'on oublie trop souvent, soit que l'on parle du droit naturel comme d'une notion purement philosophique, sans lien avec le Christ, soit au contraire que l'on parle de l'imitation du Christ en sous-estimant le droit naturel, oubliant, que Fils de Dieu a été homme total; en d'autres termes, séparer le Christ du droit naturel revient à mutiler dans son fond le message évangélique", Aubert, Loi de Dieu..., 75-76. Według $\mathrm{H}$. de Lubaca czlowiek jest niezrozumiały bez uwzględnienia pełnych wymiarów teologicznych, określających jego byt. Skierowanie człowieka ku nadprzyrodzoności, tkwiące konkretnie w jego bycie, nie jest rozpoznawalne jako takie samym rozumem czy doświadczeniem psychologicznym. Dopiero Chrystus objawiając nam Boga, objawil nam wszystko, czym jesteśmy jako ludzie. Por. Une double tâche proposée au théologien par Gaudium et Spes, w: Théologie d'aujourd-hui et de demain, Paris 1967, 47-48.

$38 \mathrm{HV}, \mathrm{nn} .4,7,11,18,20,28$.

$39, \ldots$ osoba ludzka ma być zbawiona a ludzkie społeczeństwo odnowione. Tak więc czlowiek w swej jedności i całości, z ciałem i duszą, z sercem, sumieniem, umysłem i wolą będzie osią całego naszego wywodu”, Gaudium et Spes, n. 3.

40 Gaudium et Spes, n. 10.

41 Gaudium et Spes, n. 41.

42 „... auctoritatem publicam in natura humana fundari", Gaudium et Spes, n. 74 .

43 Gaudium et Spes, n. 76. Kościół uczy, że kompetencje państwa są ograniczone ze wględu na ,transcendentalny charaktes osoby ludzkiej”. Kościół natomiast, właśnie ze względu na podkreślony wyżej charakter osoby ludzkiej, może wydawać oceny moralne nawet w tzw. kwestiach politycznych.

44 Gaudium et Spes, n. 79.

45 Gaudium et Spes, n. 89. 
lecz Kościół głosi prawo naturalne i wiąże sumienia wiernych tą powagą, która mu przysługuje jako tłumaczowi Objawienia, z którym prawo naturalne jest ściśle związane" ${ }^{46}$. Można jeszcze iść dalej i powiedzieć, że więź prawa naturalnego $\mathrm{z}$ objawieniem jest tak ściśla, że nakazy prawa naturalnego obowiązują jako równocześnie nadprzyrodzone ${ }^{47}$.

Podsumowując krótko ostatnie wypowiedzi można powiedzieć, że Kos̉ciół jako autorytatywny tłumacz prawa naturalnego może 1. - ustalić sens definicji prawa naturalnego głoszonego przez siebie, 2. - ustalić zawartość i zakres treściowy norm etycznych prawa naturalnego, 3. - określać charakter powinności i charakter mocy wiążącej w sumieniu.

Kościół jednak dotąd nie skodyfikował wszystkich norm prawa naturalnego i napewno tego nie zrobi, ale niektóre normy uzyskały już w ciągu nauczania kościelnego dość precyzyjne określenie a także wysoką rangę w hierarchii głoszonych zasad. Owszem, niektóre można uważać za należące do zakresu nieomylnej i nieodwołalnie obowiązującej doktryny Kościoła. Na tle encykliki jest jasne, że do takich zasad należy zaliczyć następujące: 1) Bóg jest panem życia oraz autorem wszystkich praw przekazywania życia, 2) Właściwą i konieczną dla człowieka formą afirmacji stworzonego charakteru ludzkiego życia jest praktyczne uznanie nietykalności stworzonych źródeł życia. Owo praktyczne uznanie nietykalności stworzonych źródeł życia polega właśnie na zachowaniu ich płciowej konstytucji, a więc na praktycznej nietykalności biologii płci.

46 Aubert, Loi de Dieu..., 78. Jest to zresztą stała nauka Kościoła wyrażona przez Piusa XII. „Quand il s'agit des avis et des presriptions que les pasteurs légitimes promulgent en matière de droit naturel, les fidèles ne doivent pas invoquer l'adage suivant: 〈tant valent les raisons, tant vaut l'auteur〉. C'est pourquoi celui que ne convainquent pas les arguments apportés par une irdonnance de l'Église garde malgré tout l'obligation d'obéir ... La puissance de 1'Église n'est pas limitée aux choses strictement religieuses comme on dit; mais toute la matière de la loi naturelle, ses principes, son interprétation, son application, pour autant qu'il s'agit de son aspect moral, relèvent de son pouvoir", All. Magnificate Dominum, AAS, 46 (1954) 672.

47 Por. Mausbach J., - Ermecke G., Katholische Moraltheologie, Bd. I: Die allgemeine Moral, Münster, ${ }^{9} 1959$, 118. „Es (= Naturgesetz) wird ein Bestandteil des neuen Gesetzes, we il und wi e die Natur ein Bestandteil der Gnadenwirklichkeit wird", tamże, 116. Por. Tettamanzi D., Humanae vitae, Milano 1968. Według tegoż autora, fakt, iż encyklika HV. głosi kompetencje Kościoła w interpretacji prawa naturalnego, jest równoznaczny $\mathrm{z}$ odrzuceniem tezy, jakoby zagadnienie regulacji poczęć leżało w zakresie jedynie „di puro diritto naturale”, w którego analizie brałoby się pod uwagę jedynie ,naturę przedmiotu”, bez uciekania się do norm abjawionych. Encyklika dowodzi, przy pomocy poważnych argumentnów, prawdziwości i słuszności tych kompetencji Kościoła. Kościół tłumacząc prawo naturalne obraca się calkowicie na swoim terenie, ponieważ przez "stworzenie w Chrystusie wszystkiego", "la legge naturale diviene parte della legge cristiana" i w ten sposób pełni rolę zbawczą. Tamże, 54-55. 


\section{UWAGI KOÑCOWE}

Z powyższych rozważań można było już wysunąć wniosek, że trudności wysuwane przeciw koncepcji prawa naturalnego w Humanae vitae nie wynikały $\mathrm{z}$ powodów rzeczowych, ale $\mathrm{z}$ przyjęcia błędnego punktu wyjścia dla analizy dokumentu kościelnego nauczania. Oczywiście, istnieją jeszcze głębsze przyczyny tego rodzaju trudności, przyczyny które nie tkwią już w samej formalnej płaszczyźnie dyskusji lecz tkwią w samych głębinach ducha ludzkiego, a bezpośrednio - w zachwianej wizji człowieka i świata. Mówimy tu o zachwianiu tej równowagi, która zależy od zachowania właściwej relacji czy proporcji między bytem skończonym (stworzonym) a Bytem Absolutnym. Równowaga ta została zachwiana nie mocą obiektywnej prawdy i oczywistości, lecz pod naporem faktów materialnych, które zamąciły jasność widzenia dzisiejszego człowieka. Postęp techniki nie jest bowiem równoznaczny $\mathrm{z}$ postępem dominacji rozumu w życiu i działaniu ludzkim. Wtargnięcie rozumu ludzkiega $\mathrm{w}$ mechanizm kosmosu sprowokowało rewanż w postaci wtargnięcia mechanicyzmu w wewnętrzny świat człowieka. Współcześni myśliciele coraz częściej i mocniej przestrzegają przed groźbą całkowitej dehumanizacji „,nowego świata" stworzonego przez człowieka ${ }^{48}$. Wizja absolutnej autonomii i autokreacji jest najbardziej kuszącą i upajającą wizją i coraz pełniej opanowuje wyobraźnię człowieka zachłyśniętego dotychczasowymi zdobyczami rozumu uzbrojonego w technikę. Jednak koniecznym i nieuchronnym rezultatem ulegania takim wizjom jest totalne zanurzenie ludzkiego losu w fale determinizmu materii.

Przy tym wszystkim już słabo dostrzega się fakt, że bezpośrednią i bardziej dla człowieka dotkliwą klęską jest rezygnacja z najszczytniejszej funkcji intelektu, jaką jest kontemplacja prawdy. Rozum człowieka technicznego staje się - na równi z maszyną, którą sam stworzył - jedynie pomocniczym elementem potężnej machiny socjo-technicznej. Taki rozum stopniowo zdaje się coraz bardziej wyłącznie na kryteria matematyczne (to jest kryteria ilości) i przestaje być zdolny

48 Por. Rahner K., Das Christentum und der „Neue Mensch”, „Schriften zur Theologie", V, Einsiedeln 21964, 159-179. - Charue A. M., Problèmes doctrinaux d'aujourd'hui, FThL, 44 (1968) 503-524. - Metz J. B., L'Église et le monde, w: Théologie d'aujourd'hui et de demain, 139-154. - Marois M., Le vertige de l'avenir scientifique, „Choisir”, 9 (1968, no 108). Ostatni autor pisze: „Voici que s'annonce prochaine l'intrusion des techniques dans le domaine inviolé de la personnalité. Les barrières de la personnalité biochimique seront rompues. Les manipulations de l'esprit deviendront faciles. L'être est cerné jusque dans sa définition; sa permanence est moins assurée. La tentation d'utiliser quoi qu'il en coûte les pouvoirs nouveaux de la science lèvera les derniers interdits des anciennes sagesses. Crise, mutation, métamorphose, sont désormais des termes usuels; ils annoncent la naissance du 〈Nouvel Adam〉. L'homme sera-t-il encore l'homme? s'nterroge Jean Rostand. Ce cri d'angoisse devrait être celui de tous les hommes de la terre"... Por. również Schlllebeeckx, Foi chrétienne et attente terrestre, 119 nn. 
oceniać swoje działanie w wymiarze wartości absolutnej. Dopóki człowiek patrzy na swoje działanie jako na proces zmierzający do jakiegoś konkretnego rezultatu i jeśli sam rezultat będzie oceniał ze stanowiska pożytku lub szkody nawet $w$ najszerszym znaczeniu tych słów, nigdy nie będzie mógł zadawalająco rozstrzygnąć żadnych problemów etycznych, a nawet nie będzie świadom, jaka droga może go do tego zbliżyć. Człowiek może zrozumieć swoje działanie jedynie w relacji do bytu - w ściśle metafizycznym znaczeniu. To zaś z kolei jest możliwe dopiero wtedy, kiedy nauczy się stykać z rzeczywistością na płaszczyźnie absolutnej prawdy i mądrości. Nie od rzeczy będzie przypomnieć na tym miejscu odnośną naukę Soboru: „,...natura intelektualnej osoby iudzkiej udoskonala się i powinna doznać udoskonalenia przez mądrość, która umysł człowieka łagodnie pociąga ku poszukiwaniu i umiłowaniu tego, co prawdziwe i dobre. Przepojony nią człowiek dochodzi poprzez rzeczy widzialne do niewidzialnych. Epoka nasza bardziej niż czasy ubiegłe potrzebuje takiej mądrości, która by wszelkie rzeczy nowe, jakie człowiek odkrywa, czyniła bardziej ludzkimi. Przyszłym losom świata grozi bowiem niebezpieczeństwo, jeśli ludzie nie staną się mądrzejsi" ${ }^{49}$.

Pozwoliliśmy sobie na te kilka uwag po to, by jeszcze raz podkreślić, że właściwe znaczenie nauki moralnej głoszonej w encyklice Humanae witae można zobaczyć i docenić dopiero wtedy, gdy na tę naukę patrzymy nie w ciasnej perspektywie polityki społecznej czy przezorności pedagogiczno-obyczajowej, lecz właśnie z najwyższych szczytów mądrości i prawdy. Papieżowi nie chodzi o to w pierwszym rzędzie, co by się stało, gdyby... itd., ale o to kim jest człowiek i jakie jest małżeństwo, kiedy się je widzi w świetle Bożym. Jeśli więc encyklika głosi jakąś normę pozytywną, to ona obowiązuje nie dlatego, że „dobrze byłoby” tak postępować, lecz dlatego, że taka jest istota człowieka i małżenstwa. Jeśli znów ukazuje normę negatywną, twierdząc, że tak nie należy postępować, to podstawą zakazu nie jest to, że w wyniku określonego postępowania mogłoby jakieś zło dotknąć człowieka czy nawet całą ludzkość, lecz zakaz wynika $\mathrm{z}$ faktu, że to działanie nie jest działaniem małżeńskim. Dobro lub zło tkwi już w samym akcie człowieka, niezależnie od tego, czy rezultat tego aktu okaże się mniej lub więcej szczęśliwy, pożądany, korzystny itp. O tym wszystkim trzeba pomiętać, jeśli się chce dobrze zrozumieć encyklikę. 


\section{R E S U M E}

\section{CONCEPTION THEOLOGIQUE DE LA LOI NATURELLE EN CONNEXION AVEC L'ENCYCLIQUE „HUMANAE VITAE”}

Dans les discussions sur la conception de la loi naturelle dans Humanae Vitae on a très souvent omis le fait, que les notions philosophiques, employées dans les documents du Magistère ecclésial, ne doivent pas être interpretées uniquement du point de vue de leur provenance philosophique ou historique, puisqu'elles sont essentiellement liées à une synthèse totalement nouvelle. Donc, on peut les comprendre uniquement en connexité avec cette nouvelle doctrine prise en totalité. Les difficultés provenant d'une définition scientifique ou philosophique de la loi naturelle ne peuvent être transférées dans le domaine, où le Magistère de l'Eglise formule ses énonciations. L'essence métaphisique de l'homme - être créé, matériel et spirituel - ne change en rien, quoique - grâce au progrès de la iscience humaine et de la technique - l'image de la nature change dans l'esprit humain, et le niveau ainsi que l'étendue de sa domination augmente constamment. D'autant plus que les vérités fondamentales anthropologiques ont trouvé leur explication et leur approfondissement dans la Révélation du Christ et le sens complet de la loi naturelle comme principe de la codulite humaine peut être déchiffré à la lumière du mystère de Jésus. C'est pour cela que l'Eglise se prononçant quant aux vérités nommées anthropologiques naturelles se réfère toujours, du moins médiatement, au critère de la Révélation. En expliquant les normes éthiques, faisant partie du domaine de la loi naturelle, l'Eglise le fait toujours d'une manière conforme à sa nature du Magistère ecclésial. Même si d'un point de vue d'une philosophie quelconque la terminologie du Humanae Vitae peut paraître controversée, elle est absolument intelligible en contexte du dogme de la Création et de l'Incarnation. Elle se trouve en accord avec les thèses anthropologiques du Concile Vatican II, qui accentuèrent non seulement le caractère personnel mais aussi intégral de la vocation humaine.

La notion biblique et intégro-personnelle de l'homme n'admet pas une séparation éthique entre la biologie du sexe et la substance même de la relation personnelle conjugale, au risque de dépersonnaliser tout le domaine charnel et, en conséquence, de déhumaniser toutes les relations humaines. 